\title{
AZ IPARI AUTOMATIZÁLÁS ÉS KOMMUNIKÁCIÓ TUDOMÁNYOS MÜHELY MUNKÁSSÁGA ÉS EREDMÉNYEI
}

\author{
Pintér Judit Mária \\ tudományos fömunkatárs, Miskolci Egyetem, Automatizálási és Infokommunikációs Intézet \\ 3515 Miskolc, Miskolc-Egyetemváros, e-mail: pinterjm@uni-miskolc.hu
}

\begin{abstract}
Absztrakt
A Miskolci Egyetemen müködö 5 Kiválósági Központ és a bennük müködő Tudományos Mühelyek fö feladata, hogy tapasztalt szenior kutatók köré eredményes kutatói csapatok épüljenek fel. A Tudományos Mühelyeken belül új kutatók kapcsolódhatnak be növelve a kutatói motiváltságot és kihasználva az interdiszciplinaritásban rejlö elönyöket. A kijelölt stratégiai kutatási témák területén cél a kutató teamek tudományos láthatóságának növelése és pozícionálása az országos, európai és még szélesebb körü nemzetközi szakmai és tudományos közegben. Publikációm célja, hogy bemutassa az Ipari Automatizálás és Kommunikáció Tudományos Mühely munkásságát és eredményeit az EFOP-3.6.1-162016-00011 jelü „Fiatalodó és Megújuló Egyetem - Innovativ Tudásváros - a Miskolci Egyetem intelligens szakosodást szolgáló intézményi fejlesztése” projekt keretén belül.
\end{abstract}

Kulcsszavak: tudományos tevékenységek, együttmüködés, mentorálás, $K+F$

\begin{abstract}
The main task of the 5 Research Centers at the University of Miskolc and the Scientific Workshops operating in them is to build effective research teams around experienced senior researchers. Within the Science Workshops, new researchers can join in, increasing researcher motivation and reaping the benefits of interdisciplinarity. In the field of designated strategic research topics, the goal is to increase the scientific visibility and positioning of research teams in the national, European and even wider international professional and scientific environment. The aim of my publication is to present the work and results of the Industrial Automation and Communication Scientific Workshop EFOP3.6.1-16-2016-00011 "Rejuvenating and Renewing University - Innovative Knowledge City - Institutional Development of the University of Miskolc for Smart Specialization” within the project.
\end{abstract}

Keywords: scientific activities, cooperation, mentoring, $R \& D$

\section{Bevezetés}

2010-ben „A felsőoktatás minőségének javítása kiválósági központok fejlesztésére alapozva a Miskolci Egyetem stratégiai kutatási területein" címü (TÁMOP-4.2.1.B-10/2/KONV-2010-0001) projekt keretében a hazai gazdaság és társadalom szempontjából kiemelt fontosságú, stratégiai kutatási területeken kiválósági központokat hozott létre, melyek fejlesztésén keresztül nemzetközi színvonalú $\mathrm{K}+\mathrm{F}+\mathrm{I}$ tevékenység müveléséhez szükséges szellemi kapacitás felépítésére törekedett. Öt olyan Kiválóság Központot hozott létre, amelyek kihasználják a Karok közötti infrastrukturális és kutatási kapacitásban meglévő szinergia lehetőségeket. Céljuk jelenleg is, hogy stratégiai partnerséget építsenek ki a Régió kulcsszereplőivel és előnyös feltételeket teremtsenek fiatal kutatók helyben tartására, mely magas színvonalú kutatási környezetet és tudományos vezetést biztosít számukra. A fiatal kutatók számára 
biztosítandó minőségi témavezetés, és a kutatási feltételek biztosítása közvetlen hatással vannak az érintett doktori iskolák képzésének színvonalára, a hallgatói tehetséggondozásra és a kutatói utánpótlásra.

A Miskolci Egyetem intelligens szakosodást szolgáló intézményfejlesztése" címü, EFOP-3.6.1-162016-00011 azonosító számú projekt a kialakított 5 Kiválósági Központ kutatói munkacsoportjaira épül és 6 részprojektre tagolódik. A projekt célja többek között, hogy a Kiválósági Központok új kutatási profilt alakítsanak ki az S3 prioritások mentén; új Tudományos Mühelyek és K+F csoportok jöjjenek létre; új kutatási témakörök kerüljenek kijelölésre a környezeti gazdasághoz és a társadalmi kihívásokhoz kapcsolódóan; növelje a hazai és nemzetközi rendezvényeken való részvételt és a publikációs tevékenységet. A projekt 4 éves futamideje alatt az Ipari Automatizálás és Kommunikáció Tudományos Műhely kitüzött céljait, megvalósított tevékenységeit és elért eredményeit az alábbi fejezetek taglalják részletesen.

\section{A Logisztikai, Informatikai, Mechatronikai Kiválósági Központ tevékenysége}

Az Ipari Automatizálás és Kommunikáció Tudományos Mühely a Logisztikai, Informatikai, Mechatronikai Kiválósági Központon belül müködik, így munkásságunk szervezesen illeszkedik a Kiválósági Központ tevékenységéhez és fejlesztési irányzataihoz.

A Kiválósági Központ (KK) célja, hogy a nemzeti intelligens szakosodási stratégia (S3) nemzeti és megyei prioritásaihoz illeszkedő $\mathrm{K}+\mathrm{F}+\mathrm{I}$ feladatokat lásson el. Ezen prioritások közül a KK szempontjából legfontosabbak:

- fejlett jármü- és egyéb gépipari technológiák;

- IKT \& szolgáltatások;

- logisztika.

Ezen $\mathrm{K}+\mathrm{F}+\mathrm{I}$ feladatok ellátásához az Észak-magyarországi régióban, növelnie kell a személyek számát az egyetemi kutatási környezet átalakításával és hallgatók ösztönzésével (pl. doktori iskolák tevékenységének felülvizsgálata, képzések kialakításánál/átalakításánál ipari szakemberek bevonása, hallgatói életpályamodell kidolgozása, bevezetése, stb.) Kiemelten fontos, hogy a hazai- és nemzetközi tudományos közéletben növelje jelenlétét és erősítse a tudástranszfer és publikációs tevékenységeit. További célja, hogy a vállalatok és az egyetem közötti együttmüködéseket erősítése (közös kutatás, ipari szakemberek képzésbe való bevonása, tudástranszfer tevékenység fejlesztése, online képzés erősítése).

A Kiválósági Központon belül az alábbi 4 Tudományos Mühely müködik, melyek több K+F csoportot fognak össze:

- Mechatronikai rendszerek és elemeinek fejlesztése Tudományos Mühely (4 K+F csoport);

- Logisztikai rendszerek hatékonyságnövelési eljárásainak, módszereinek kutatása Tudományos Mühely (11 K+F csoport);

- Ipari Automatizálás és Kommunikáció Tudományos Mühely (6 K+F csoport);

- Informatikai Tudományok Tudományos Mühely (4 K+F csoport).

\section{Az Ipari Automatizálás és Kommunikáció Tudományos Mühely tevékenysége}

Az Ipari Automatizálás és Kommunikáció Tudományos Mühely a projekt kezdetekor az alábbi $\mathrm{K}+\mathrm{F}$ csoportokat fogta össze:

- Intelligens gyártás;

- Intelligens jármúvek, közlekedés; 
- Beágyazott rendszerek és IoT (Internet of Things);

- Beszéd- és képfeldolgozás alapú interfészek;

- Ipari kommunikációs rendszerek;

- Az irányításelmélet és az automaták elmélete.

A Tudományos Műhely a projekt futamideje alatt a kitüzött célokkal szinkronban felülvizsgálta $\mathrm{K}+\mathrm{F}$ tevékenységeit az $\mathrm{S} 3$ prioritások mentén, nagy hangsúlyt fektetett az utánpótlás nevelésre, a publikációs tevékenységre, a mentori tevékenységekre és a szakmai rendezvényeken/versenyeken való részvételre nemzetközi szinten is.

A Gépészmérnöki és Informatikai Kar 2017-ben alapított Terplán Zénó Szakkollégium munkásságában és életében szervesen is részt veszünk. A közös munka eredményeként jelentősen erősödött mentori tevékenységünk és lehetőség nyílt több alapszakos és mesterszakos hallgató számára, hogy konferenciákon is bemutassák eredményeiket. A Szakkollégium támogatásával több fejlesztési terv a gyakorlatban is megvalósulhatott.

A Tudományos Mühely munkálataiba a 4 év alatt 15 alap- és mesterszakos hallgató és $7 \mathrm{PhD}$ hallgató került bevonásra, 4 kollégánál pedig formális szintlépés történt. 43 publikáció került megjelenésre, számos hazai és nemzetközi konferencián bemutattuk eredményeinket. A 4 év alatt rendszeresen részt vettünk szakmai és toborzó rendezvényeken, több középiskolában tartottunk beiskolázási előadásokat az Észak-magyarországi Régióban. 2018-ban a 19th International Carpathian Control Conference -IEEE (ICCC2018) konferencia főszervező intézménye voltunk.

\subsection{Kutatási területek}

A Tudományos Mühelyben tevékenykedő Kollégák és a kutatásokba bevont hallgatók a projekt keretén belül az alábbi szakterületeken végeztek $\mathrm{K}+\mathrm{F}$ tevékenységet, majd eredményeiket publikációs formában is megjelentették:

- gépi látás alapú rendszerek tervezése és képfeldolgozó alkalmazások fejlesztése [1];

- autonóm jármümodell irányítórendszerének fejlesztése [2];

- beszéd alapú érzelemfelismerés [3];

- intelligens vezérlő rendszerek fejlesztése és integrálása meglévő épületautomatizálási rendszerekbe [4];

- nyelvkontúr automatikus követése ultrahangos felvételeken [5];

- etológiai viselkedésmodellek alapjául szolgáló fuzzy szabály interpolációs eljárás és a FIVE beágyazott rendszereken történő megvalósíthatóságának vizsgálata [6,7];

- modern AI algoritmusok futtathatóságának vizsgálata FPGA környezetben [8];

- logisztikai rendszerek hatékonyságnövelése hangvezérelt rendszerek alkalmazásával [9];

- digitalizáció a logisztikában [10];

- komfort paraméterek mérésére alkalmas szenzoros egységek fejlesztése [11];

- mérnöki gyakorlatban előforduló, fizikai paraméterektől függő matematikai modellek analitikus és numerikus vizsgálata (parciális differenciálegyenletek és egyenletrendszerek analitikus és numerikus vizsgálata) $[12,13]$;

- mágneses térben laminárisan áramló ferrofluid sebesség és hőmérséklet eloszlását leíró modellek vizsgálata [14];

- a teljes mátrix algebrán a kommutátorral képzett Lie algebrának a vizsgálata [15]. 
A $\mathrm{K}+\mathrm{F}$ tevékenységeknek köszönhetően, az elért eredmények beépítésre kerültek az oktatási anyagokba és két új $\mathrm{K}+\mathrm{F}$ csoportot hoztunk létre az Ipari Automatizálás és Kommunikáció Tudományos Mühelyen belül:

- Épület automatizálás - öntanuló intelligens vezérlések;

- Szenzor technológia.

\subsection{Hazai és nemzetközi versenyek}

Számos szakmai rendezvény közül (szakmai napok, országos rendezvények, nemzetközi konferenciák, workshopok stb.) az alábbi 4 hazai és nemzetközi verseny kiemelt szereppel bírt az elmúlt 4 évben. A Tudományos Műhely utánpótlás nevelésében és a hallgatók motiválásában kiemelt szerepet játszanak a mai napig. Számos TDK dolgozat, szakdolgozat, diplomamunka és publikáció íródott a hallgatók munkáiból. A szakmai versenyeken való részvétel és azok szervezésében való közremüködés elősegítette, hogy új ipari partnerségeket alakítsunk ki, továbbá növelte a nemzetközi láthatóságunkat is.

- Alkalmazott Mérnöki Tudományok Országos Robotversenye: másnéven a Magyarok a Marson 2006-ban került elöször megszervezésre. Minden évben a kiírt versenyfeladatnak megfelelő robotot kell építeniük a csapatoknak, amelyek a megépített versenypályán körmérkőzésekkel szereznek pontokat és a végső sorrendet a szerzett pontok összessége adja. A Miskolci Egyetem hallgatói és oktatói 2015-ben kapták meg a lehetőséget, hogy befogadó intézmény lehessen. Azóta 3 sikeresen megrendezett versenyen vagyunk túl. Az elmúlt éveket tekintve rengeteg tapasztalatot szereztek a hallgatók és mi magunk, szervezők is. Nem csak a robotok megtervezése jelentett kihívást, hanem a pályatervezés és megvalósítás, valamint a szervezés, kiemelten pedig a szponzorációs tevékenyégek. Az elmúlt években közel 200 versenyző vett részt a versenyen (ipari szakemberek, egyetemi hallgatók, középiskolai diákok, általános iskolások), melyek közül 48 a Miskolci Egyetemet képviselte. Az elmúlt 4 évben 12 TDK dolgozat 9 publikáció és több szakdolgozat is született a témában, az elkészült robotok pedig a gyakorlati órákon és egyetemi nyílt rendezvényeken kerülnek bemutatásra [15].

- Solar Decathlon Europe 2019: a nemzetközi innovációs passzívház építő verseny központi célja a megújuló energiák, köztük kiemelten a napenergia (ahogyan az a verseny nevéböl is adódik) és az innovatív technológiák alkalmazásával összefüggő építészeti megoldások népszerüsítése az egyetemista csapatok által felépített pályamüveken keresztül. A csapat végső összetételét a Miskolci Egyetem, a Pécsi Tudományegyetem és az algériai Blidai Egyetem alkotta. A verseny remek lehetőséget nyújtott, hogy a gyakorlatban is megmutatkozzon az egyetemek közötti együttmüködés sikeressége, nem csak hazai, hanem nemzetközi vonalon is. A csapat közel 80 föből állt 65 ipari partner/szponzor, számtalan kolléga és barát segítette időszakosan munkánkat. A pályamunkát többszörösen is díjazta a nemzetközi zsüri [4].

- Formula Student: a Formula Racing Miskolc egy olyan hallgatói öntevékeny kezdeményezés, mely által a csapat tagjai mélyreható ismeretet és tapasztalatot szerezhetnek a jármüipari és autósport különböző ágazataiban. Megtanulhatják az igazi csapatmunka jelentését, valamint kamatoztathatják elméleti tudásukat a gyakorlatban. A projekt lehetőséget biztosít a legfejlettem technológiák megismerésére és alkalmazására, valamint az ipari cégek irányába való indirekt csatornaként szolgál a benne szereplő hallgatók számára. A Formula Student konstruktőri mérnökverseny célja egy olyan formula autó tervezése, kivitelezése és képzeletbeli piacra bocsátása, melyet hallgatói jogviszonnyal rendelkező diákok valósítanak meg és versenyeztetnek nemzetközi színtéren. A mozgalom célja a gyakorlatorientált munkatapasz- 
talat megszerzése mellett, egy olyan csatorna kiépítése, mely gördülékeny kommunikációt biztosít a Formula Studentben résztvevő hallgatók és a törekvést támogató cégek között. Ezen versenyek számos európai országban kerülnek megrendezésre [2, 17].

- Országos Ajtonyi István Irányítástechnikai Programozó Verseny: az Automatizálási és Infokommunikációs Intézet - mely a Tudományos Mühely egyik tagja - a kezdetek óta a Felsőoktatási Irányítástechnikai Oktatásmódszertani Egyesület része, amely a felsőoktatásban az irányítástechnika és a gyakorlatorientált képzés mellett elkötelezett felsőoktatási szervezetek közös céljainak megvalósítása érdekében „született”. Az Egyesület és a Miskolci Egyetem meghatározó személyisége volt Prof. Dr. Ajtonyi István, akiről maga a verseny is elnevezésre került. A verseny napjainkra nemzetközivé nőtte ki magát, hiszen szomszédos országok egyetemi is képviseltetik magukat a megmérettetésen. A rendezvénynek minden évben az egyesület valamelyik tagintézménye add otthont és gondoskodik a szervezésről. A verseny az iparban is kiemelt figyelmet élvez, hiszen minden jelentős PLC gyártó cég szponzorként is képviselteti magát a rendezvényen. ezért kapcsolatépítés szempontjából is kiemelt jelentőséggel bír részvételünk.

\section{4. Összefoglalás}

Az elmúlt négy évben az Ipari Automatizálás és Kommunikáció Tudományos Mühely jelentős fejlődésen és átszerveződésen ment át. A projekt és az időszak adta lehetőségek által új $\mathrm{K}+\mathrm{F}$ csoportok kerültek kialakításra és a már meglévő területeken új specifikus kutatások jöttek létre. Rengeteg tapasztalatot szereztünk nemzetközi és hazai versenyeken való részvételen. Nemzetközi és hazai láthatóságunkat pedig megerősítettük rendezvények szervezésével, konferenciákon, workshopokon való részvétellel és publikációs tevékenységeinkkel. Mentori tevékenységünket megerősítettük a Terplán Zénó Szakkollégiummal való együttmüködés révén. A létrejött TDK dolgozatok, szakdolgozatok, diplomamunkák és a témavezetőkkel közösen írt publikációk hủen tükrözik a gyakorlatorientált mentori tevékenységünket.

\section{Köszönetnyilvánítás}

A cikkben ismertetett kutató munka az EFOP-3.6.1-16-2016-00011 jelü „Fiatalodó és Megújuló Egyetem - Innovatív Tudásváros - a Miskolci Egyetem intelligens szakosodást szolgáló intézményi fejlesztése" projekt részeként - a Széchenyi 2020 keretében - az Európai Unió támogatásával, az Európai Szociális Alap társfinanszírozásával valósul meg.

\section{Irodalom}

[1] Trohák, A., Forgács, Zs.: Tananyagok modernizálása az ipar 4.0 követelményei kapcsán, 2018 Számítástechnika és Oktatás Konferencia, Tusnádfürdő, Románia, pp. 341-344.

[2] Máté, K.: Formula Student versenyautó elektromos rendszerének felépitése, Multidiszciplináris Tudományok, 10(4), (2020) pp. 112-118. https://doi.org/10.35925/j.multi.2020.4.14

[3] L. Kiss, M., Pintér, J. : Érzelemfelismerö interfész koncepcionális tervezése okosotthon rendszerhez, Multidiszciplináris Tudományok, 10(4), (2020) pp. 219-226. https://doi.org/10.35925/j.multi.2020.4.26

[4] Pinter, J. M., Czap, L., Marton, L. K.: Development of speech-based interface for smart home systems, 2018 19th International Carpathian Control Conference (ICCC), pp. 348-352. IEEE. https://doi.org/10.1109/CarpathianCC.2018.8399654 
[5] Zhao, L., Czap, L.: Lip viseme analysis of Chinese Shaanxi Xi'an dialect visual speech for talking head in speech assistant system, In: Journal of Physics: Conference Series. IOP Publishing, (2021) pp. 042-043.

[6] Bartók, R., Vásárhelyi, J.: A FIVE módszer párhuzamosithatóságának vizsgálata Parallella mikroszámitógépen, ENELKO 2018 XIX. Nemzetközi Energetika-Elektrotechnika Konferencia, Erdélyi Magyar Müszaki Tudományos Társaság (EMT), pp. 134-139.

[7] Bartók, R., Vásárhelyi, J.: Fuzzy rule interpolation based object tracking and navigation for social robot, Lecture Notes in Mechanical Engineering, (2018) pp. 370-375. https://doi.org/10.1007/978-3-319-75677-6_31

[8] Bouzid, A., Vásárhelyi, J.: Implementation and experimentation of an embedded data acquisition/preprocessing system based on a hybrid reconfigurable hardware accelerator for inertial measurements, IEEE Transactions on Industry Applications, 56 (2), (2020) pp. 2012-2019. https://doi.org/10.1109/TIA.2020.2965888

[9] Varga, A. K.: Development of a web-based R\&D\&I system for the University of Miskolc, Chapters from the Academic Aspect of Project Management-Research and Teaching Methodologies, (2020) p. 179.

[10] Illés, B., Varga, A. K., Czap, L.: Logistics and digitization, In Vehicle and Automotive Engineering, (2018) pp. 220-225. Springer, Cham. https://doi.org/10.1007/978-3-319-75677-6_18

[11] Pinter, J., L. Kiss, M.: Determination and measurement of parameters affecting indoor comfort, 2019 20th International Carpathian Control Conference (ICCC). IEEE, pp. https://doi.org/10.1109/CarpathianCC.2019.8766035

[12] Hriczó, K.: Boundary value problem for a heated nanofluid flow in the presence of magnetic field, International Journal of Engineering and Management Sciences 4 (1), (2019) pp. 58-66. https://doi.org/10.21791/IJEMS.2019.1.8.

[13] Barna, Bognár, G., Guedda, M., Mátyás, L., Hriczó, K.: Analytic self-similar solutions of the Kardar-Parisi-Zhang interface growing equation with various noise terms, Mathematical Modelling And Analysis 25 (2), (2020) pp. 241-256. https://doi.org/10.3846/mma.2020.10459

[14] Bognár, G., Hriczó, K.: Ferrofluid flow in magnetic field above stretching sheet with suction and injection, Mathematical Modelling and Analysis 25 (3) (2020), pp. 461-472. https://doi.org/10.3846/mma.2020.10837

[15] Szigeti, J., Van den Berg, J., Van Wyk, L., Ziembowski, M.: The maximum dimension of a Lie nilpotent subalgebra of $\mathbb{M}_{-}\{\mathbb{M}\}(\mathbb{F})$ of index $\mathbb{m}$. Transactions of the American Mathematical Society, 372 (7), (2019) pp. 4553-4583. https://doi.org/10.1090/tran/7821

[16] L. Kiss, M.: Hand-drawn characters sensing with accelerometer, 2019 MultiScience-XXXIII. microCAD International Multidisciplinary Scientific Conference, Miskolci Egyetem, pp. 1-5. Paper: D2-10 , 5 p. https://doi.org/10.26649/musci.2019.045

[17] Anga, D., Koba, M.: Autonóm jármümodell fejlesztése, Multidiszciplináris Tudományok, 10 (2), pp. 413-420. https://doi.org/10.35925/j.multi.2020.2.46 